\title{
Religious Activities of Clerks of Russian Origin Employed in the Regional Branches of Customs Tariff Department in the Kingdom of Poland Between 1851 and 1914*
}

Aktywność religijna urzędników pochodzenia rosyjskiego struktur terenowych Departamentu Opłat Celnych w Królestwie Polskim w latach 1851-1914

\begin{abstract}
Since 1851 Russian customs administration operated on the territory of the Kingdom of Poland. In the local structures of the Customs Duties Department of the Ministry of Finance there appeared many clerks of Russian origin and Orthodox denomination. First Russian local communities started to emerge and they were frequently centred around newly erected Orthodox churches. Throughout the whole period when this administration was present in the Kingdom of Poland, between mid-1800s and 1914, customs officers and border guards became willingly involved in numerous projects related to the operation of the Orthodox church. Tsarist administration was highly supportive of such bottom-up initiatives. They eagerly accepted clerks' engagement in church building committees, in establishment and operation of church-parish charity committees or religious fraternities. The willingness to help one's own church or poor parishioners had a mobilizing effect on the representatives of Russian clerical intelligentsia employed in the customs department. These initiatives grew in number after 1864 and were noticeable until the outbreak of World War I.
\end{abstract}

Key words: clerk, customs office, Russian, Orthodox church

* The present article was created as an outcome of the research project of the National Science Centre, Poland, no. 2015/19/B/HS3/01132, entitled Customs administration in the Kingdom of Poland in the years 1851-1914. Competences-structures-people. Полное собрание законов Российской Империи, собрание второе, vol. XXV, отделение второе, 1850, no. 24598, Санкт Петербург 1851, рр. 48-176. 
The second half of 1840 s witnessed discussions aimed at laying down new regulations on the functioning of the Kingdom of Poland in the customs structure of the Russian Empire. These discussions were conducted in the Ministry of Finance, with the cooperation of the clerks representing the Chancellery of the Namestnik of the Kingdom of Poland and the Governmental Commission of Incomes and Treasury. As a result, a new customs bill for the Kingdom of Poland was created, which was put into force by the $u k a z$ of Tsar Nicholas I of 5/17 November 1850. According to its regulations the Kingdom of Poland was no longer a separate customs area with its economic autonomy, which would gather profits from duties imposed on the goods brought to its area since $1 / 13$ January $1851^{1}$.

Another consequence of the new customs bill on the area of the Kingdom of Poland was institution of new staff posts in customs offices and border guard units. This, in fact, meant establishment of the organs of customs administration modelled on those functioning in the Russian Empire as subordinated to Department of Foreign Trade of the Ministry of Finance (DFTMF). New customs offices and adjacent customs units were to replace Polish customs offices. The commencement of the activity by typically Russian customs officers also resulted in the obligation to conduct all correspondence in the official language that was obligatory on the whole territory of the Tsar's empire. Also the way chancelleries were organised in those offices was the same as in the customs units in other parts of Russia. All of this resulted in the appearance of clerks of Russian origin in those offices from 1/13 January $1851 \mathrm{on}^{2}$.

It needs to be noted that the nominations of clerks for posts in the units of customs administration in the Kingdom of Poland were decided based on the agreement between DFTMF and the Namestnik of the Kingdom of Poland (Customs Department of the Chancellery of the Namestnik of the Kingdom of Poland) ${ }^{3}$. Initially, few Russians joined service in the structures of customs offices in the Kingdom of Poland even though the clerks previously employed in the mainland of the Russian Empire were given priority when being admitted to service. A significantly higher number of them joined the corps of the border guards (officers and lower-rank staff). The available sources make it possible to put forward a claim that Russians constituted up

1 Полное собрание законов Российской Илиерии, собрание второе, vol. XXV, отделение второе, 1850, по. 24598, Санкт Петербург 1851, pp. 48-176.

2 See Rossiyskiy Gosudarstvennyy Istoricheskiy Arkhiv [hereinafter: RGIA], f. 1349, inv. 5, ref. no.: 2753, 3914, 5253, 7126.

3 K. Latawiec, Rosyjska straż graniczna w Królestwie Polskim w latach 1851-1914, Lublin 2014, pp. 49-51. 
to $25 \%$ of all customs administration workforce ${ }^{4}$. This proportion got significantly changed after the outbreak of the January Uprising. In 1864 the Customs Department of the Chancellery of the Namestnik of the Kingdom of Poland was liquidated and the competence to nominate clerks was passed over to its successor, Customs Tariffs Department of the Ministry of Finance (CTDMF) ${ }^{5}$. It was then that the personnel employed at top posts got replaced. In particular, the clerks of Roman Catholic denomination were replaced by those belonging to the Russian Orthodox Church. It must be noted that such an action was caused by the desire to prevent the situation which took place in 1863, when some of the Polish-origin staff employed at customs offices joined the January Uprising. That is the reason why in the second half of 1860s the Russian element in the clerk corps employed in the customs administration was significantly increased. The adopted regulations on staff employment policy in customs administration offices were enforced also in the upcoming decades until its termination in the Kingdom of Poland at the end of July $1914^{6}$.

The appearance of a bigger number of Russian-origin staff triggered the process of formation of Orthodox church communities in the borderland areas of the Kingdom of Poland. The Russian Orthodox denomination, as a state religion in the Russian Empire, was one of the foundations of the then-current socio-political order of the Romanov state. It played a very important role in the in-service and out-of-service activities of administration staff. They were obliged to participate in religious ceremonies organised to commemorate typical state, court or church festivals.

When introducing the units of customs administration in the Kingdom of Poland the Russian government was aware of the possibility of appearance of a considerable number of Orthodox clerks. No wonder, then, that one of the articles of the customs bill for the Kingdom of Poland featured a regulation referring to a necessity of construction of six Russian

4 Calculations based on: RGIA, f. 1349, inv. 5, ref. no.: 828, 1467, 2066, 2216, 2443, 2753, 3174, 3294, 3914, 5033, 5253, 5293, 5692, 6464, 7126, 7398, 7915, 8178, 8976, 9138.

5 The hypothesis based on source materials retrieved as a result of research queries in the Russian State Historical Archives in Sankt Petersburg, State Archive of the Russian Federation in Moscow and Latvian State Historical Archives in Riga.

6 RGIA, f. 908, inv. 1, ref. no. 329; Rocznik urzędowy obejmujacy spis naczelnych władz Cesarstwa oraz wszelkich władz i urzędników Królestwa Polskiego na rok 1862, Warszawa [no date of publication], pp. 343-359; Rocznik urzędowy obejmujący spis naczelnych władz Cesarstwa oraz wszelkich władz i urzędników Królestwa Polskiego na rok 1863, Warszawa [no date of publication], pp. 404-424; Rocznik urzędowy Królestwa Polskiego na rok 1866, Warszawa [no date of publication], pp. 536-553. 
Orthodox churches for the customs department staff 7 . This was a novelty, since rarely would an official document make legal provisions for the construction of Orthodox churches. Such a move was also conditioned by an insufficiently developed network of Orthodox parishes in the territory of the Kingdom of Poland. In the early 1850s the clerks could only use very few civilian churches, what is more, quite remote from the borderland. There was also a possibility to make use of military churches operating with the Russian army units positioned in the Kingdom of Poland.

The institution of churches for the customs department was done with great tardiness. Even though on 1/13 January 1851 the first clerks of Orthodox denomination appeared, the access to churches designated for the DFTMF staff was provided to the clerks only after several months, at the turn of 1851. What is worse, these churches were instituted in other places than the ones designated by the customs bill. The churches were located in the following places: Łomża, Mława, Słupca, Praszka, Wilczkowice and Zawichost. These were either the localities of customs offices (Słupca, Praszka, Mława) or of customs district management boards (Łomża, Zawichost) ${ }^{8}$. Such a placement did not last long. As early as in the first half of 1850s some of them changed location - in particular, the church from Wilczkowice was moved to Michałowice (the seat of the customs office) and subsequently to Olkusz, where it was operating until the early 1890s. Similarly, the church from Praszka was located in Krzepice 9 . It should be noted that in the subsequent decades new churches designated for the customs department were either instituted (Kibartai, Sub-border Aleksandrów, Grajewo, Granica) or already existing ones

7 In 1851 there were plans to erect Orthodox churches in the following localities of customs offices: Bogusze, Zieluń, Skulsk, Niezdara, Igołomia, Krzeszów. Each of the planned districts was supposed to have two churches. Ustawa celna dla Królestwa Polskiego, Warszawa 1851, p. 87.

8 K. Latawiec, Duchowieństwo cerkwi prawosławnych resortu celnego i straży granicznej w Królestwie Polskim w latach 1851-1914, 'Res Historica' 2014, 37, pp. 199-200; idem, Rosyjska straż graniczna, pp. 370-371.

Archiwum Narodowe w Krakowie, Akta stanu cywilnego Parafii Prawosławnej w Olkuszu, ref. no. 1, passim; Archiwum Państwowe w Częstochowie, Akta stanu cywilnego Parafii Prawosławnej w Krzepicach, ref. no.: 1-12, passim; Archiwum Państwowe w Katowicach, Akta stanu cywilnego Parafii Prawosławnej w Olkuszu, ref. no.: 1/60, 2/12, 2/35, passim; Archiwum Państwowe w Kielcach, Oddział w Sandomierzu, Akta stanu cywilnego Parafii Prawosławnej p.w. św. Michała w Zawichoście, ref. no. 2, passim; Archiwum Parafii Prawosławnej w Częstochowie, Akta stanu cywilnego Parafii Prawosławnej w Olkuszu, Księga chrztów z lat 1857-1864, passim; P. Słowiński, Prawosławie w Sandomierzu i okolicy, Warszawa 2008, pp. 21-22; K. Latawiec, Rosyjska straż graniczna, pp. 371-372. 
were moved to new locations ${ }^{10}$. These churches were functioning until the outbreak of World War I when their operation was suspended due to military activities and evacuation of customs administration units.

The Russian-origin clerks employed at DFTMF and CTDMF were very closely affiliated to the Russian Orthodox church, which was one of the distinguishing features of Russian clerical communities in the territory of the Kingdom of Poland. Such a close linkage was caused by a number of factors. First of all, the fact of belonging to the Russian Orthodox church of a given person started upon baptism. Next, due to education at home and active participation in religious life this devotion was intensified. Obviously, the degree of involvement in religious life of adults was exclusively up to the own will of a given clerk. The need of intensification of activities for one's church or parish community depended on individual decisions of a particular person.

Apart from clerks' individual decisions on their religious involvement also external stimuli encouraging consolidation of Russian clerical communities of Orthodox denomination need to be mentioned here. Together with the appearance of Orthodox churches dedicated to DFTMF in the borderland area, the Orthodox denomination was not followed by too great a number of believers among the indigenous people of the Kingdom of Poland. A Russian clerk of Orthodox denomination was an alien element in that area. This is why the surrounding, foreign in terms of ethnicity and denomination encouraged speeding up the development of numerous religious initiatives connected with the functioning of the Orthodox church in the described area. The construction of Orthodox churches and all possible religious initiatives connected with them made it easier for prospective clerks to find their way around the area which was completely new to them and enabled them to recreate the reality of the socio-religious life that they previously enjoyed in the mainland of the Russian Empire.

The moment the churches within the structures of the Russian Orthodox church were instituted, there appeared first opportunities for clerks of this department to become involved in religious activity. This was enabled by the legal regulations adopted already at the beginning of the $19^{\text {th }}$ century, which specified the range of competences and spheres of activity of socalled Orthodox church starosts. Their activities were regulated by the $u k a z$ of the Tsar of 17/29 April 1808 and further acts (ukazes and decrees after 1808) issued by the Most Holy Governing Synod or signed by the

10 The location of the churches of interest got changed: from Zawichost to Sandomierz, from Krzepice to Praszka and to Wieluń, from Łomża to Piątnica. P. Słowiński, op. cit., pp. 23-24; K. Latawiec, Rosyjska straż graniczna, pp. 372-375. 
ruling tsar. According to the laws regulating the activities of Orthodox church starosts, a person occupying that position was a plenipotentiary of all parishioners of a particular Orthodox church, elected out of their community and enjoying their respect and confidence. Starosts were in charge of finances and estate of the parish. What is more, this person was authorized to spend money belonging to the parish community. Starosts were elected by parishioners for 3-year terms. The election had to be approved of by a local parish priest and church service (dyak, psalmist, bell-ringer). Subsequently, through the mediation of the district dean (supervising the area in which a given church was located) the candidate was proposed to the archbishop (in charge of the diocese), who authorized a particular person to occupy this position. One and the same person could be elected for numerous term $\mathrm{s}^{11}$. While taking office a starost would control personal and real property of the church based on the inventory previously authorized by the authorities of the diocese (consistory). The people who were put in charge of representing the parish community were obliged, among others, to participate in negotiations on purchase of land for a new church, a cemetery or other parish buildings.

The starosts of customs-border churches (the term adopted and functioning in the administrative discourse in the $19^{\text {th }}$ century) were nominated mainly out of clerks employed in the structures of customs administration, border guards, or, in very rare cases, in general administration. Why were these duties confided in customs officers? Once the churches under description were instituted, all customs officers of Orthodox denomination, apart from border guards, were the core of parish communities. The election for the position of a church starost was mainly conditioned by: the respect enjoyed by a given clerk among the members of the parish community, the occupied post (for instance, chief of a customs district, a person in charge of a customs office) and close relations with the parish priest. Due to incomplete sources, unfortunately, it is not possible to give a clear and precise answer to the question who and when was a church starost in the Orthodox churches of the customs department of the Kingdom of Poland. However, the purpose of the church and the composition of parish communities resulted in the fact that, for sure, the church starosts in the years 1851-1876 comprised the persons of interest to our discussion here ${ }^{12}$.

11 Приложение к 'Холмско-Варшавский Епархиальный Вестник' [hereinafter: 'XBEB'] 1877, 2, p. 1.

12 For the first twenty-five years of functioning of customs churches in the Kingdom of Poland historians have no sources represented by files which would be created as a result of activities of these structures of the Orthodox church as they got destroyed. 
With the establishment of the Chełm-Warsaw Orthodox diocese on the area of the Kingdom of Poland and the publication of the official press release of its church structures a closer look could be taken at the issue of presence of employees of the customs department in the church structures. Late in the summer of 1877 Vasiliy Konstantinovich Zguromaly, a specialtask clerk with the chairman of Wierzbołów ${ }^{13}$ Customs District, gained approval of the parish community as well as was authorized by the priest of the local church to be the starost. In October 1877 the Chełm-Warsaw archbishop authorized this clerk to be the starost of the Tsar Konstantin Orthodox church in Łomża ${ }^{14}$. V. K. Zguromaly was the head of the parish community for the next couple of years. He had to leave office once accepting the position of the chairman of Wincenta customs office. As his replacement, the parishioners elected captain of Wierzbołów Border Guard Brigade Michał Szkura in the first weeks of $1881^{15}$.

One month later the head of the battalion of Aleksandrów Border Guard Brigade, major Yelisey Novoselskiy, who was authorized by the ChełmWarsaw archbishop on 3/15 December 1877, was elected as the starost by the parishioners of the church in Słupca ${ }^{16}$. Novoselskiy occupied this position for less than a year since at the end of December 1878 those duties were conferred to another chief of the $5^{\text {th }}$ Batallion of Aleksandrów Border Guard Brigade lieutenant colonel Vasiliy Lizandrov. After completing a three-year term this officer was re-elected for the second term of the same length ${ }^{17}$. Similarly to his predecessor, Lizander also did not manage to complete his full second term. In August 1884 the commander of Słupca unit from Aleksandrów Border Guard Brigade lieutenant prince Nikolay Trubetzkoy became a new church starost ${ }^{18}$.

It needs to be noted that the employees of the customs department were often involved in the activities of parish communities of civilian churches located in the area of the Kingdom of Poland. One of them was situated in Częstochowa. Its construction was completed at the end of October $1872^{19}$. Active believers in that church were the customs officers employed in the chancellery of the management of Kalisz Customs District, which

13 Wierzbołów is currently in the territory of Lithuania under the name of Virbalis.

14 'XBEB' 1877, 5, p. 9.

15 'XBEB' 1881, 11, p. 162; K. Latawiec, Rosyjska straż graniczna, pp. 395-396.

16 'XBEB' 1878, 1, p. 8; K. Latawiec, Rosyjska straż graniczna, p. 395.

17 'XBEB' 1882, 1, pp. 3-4; K. Latawiec, Rosyjska straż graniczna, p. 395.

18 'XBEB' 1884, 17, p. 251; K. Latawiec, Rosyjska straż graniczna, p. 395.

19 This is evidenced by the records in the registral books kept by the parish priest. See Archiwum Państwowe w Częstochowie, Akta stanu cywilnego Parafii Prawosławnej w Częstochowie, ref. no. 1; Archiwum Parafii Prawosławnej w Częstochowie, Akta stanu cywilnego Parafii Prawosławnej w Częstochowie, ref. no. year 1872. 
was chaired by active state councillor Alexander Nikanorovich Kurlov ${ }^{20}$. Sometimes the position of a church starost of this particular church involved the people discussed herein, for instance, since 27 November/9 December 1878 this position in Częstochowa was occupied by captain Nicholas Shestakov from Kalisz Border Guard Brigade ${ }^{21}$.

Occupying the position of a starost by employees of the customs department (civilian clerks and border guards) brought about much benefit to particular churches. Each church was permanently supported by money donations collected among parishioners represented by customs officers or serving in the units guarding the country's borders. These donations were essential for everyday functioning of the church, such as purchases of wax candles, devotional articles of different kinds, etc. Starosts took as much care as possible of the church, being aware of the fact that its good state is the showcase of all the parishioners. After three years of performing this honourable position, starosts were put to test through being subjected to elections for another term in office. It is worth noting that church starosts did not receive any remuneration for their activity and for many of them these activities were done outside of regular service. Obviously, meeting one's aims related to taking care of the well-being of one's parish church was facilitated by the position occupied in the hierarchy of state administration offices. However, such activities had a noble aim and were accomplished outside of regular duties in office.

At the turn of 1850s the Empire witnessed an accelerated process of development of organisations supporting the activities of Orthodox church parishes. The activities of the emerging institutions were focused on taking care of parish churches. Being aware of the need to make this process regulated by a certain legal framework, on 2/14 August 1864 the Most Holy Governing Synod issued the regulations of creation and operation of parish charity committees (приходских попечительств). The process of instituting church-parish charity committees in the Kingdom of Poland started in mid $1860 \mathrm{~s}^{22}$.

The first such institution located with customs-border churches appeared as early as two years after the regulations on their functioning came into force. On 1/13 September 1866 a church-parish charity committee started its operation with the customs church in Łomża.

20 K. Latawiec, A. Górak, J. Legieć, S. Bogdanow, Naczelnicy organów rosyjskiej administracji specjalnej w Królestwie Polskim w latach 1839-1918. Stownik biograficzny, vol. 2, Ministerstwo Finansów, Lublin 2016, pp. 108-110.

${ }^{21}$ 'XBEB' 1879, 2, p. 24; K. Latawiec, Rosyjska straż graniczna, p. 396.

22 'XBEB' 1878, 18, pp. 3-5; no. 19, pp. 3-5; no. 20, pp. 4-6; K. Latawiec, Rosyjska straż graniczna, pp. 396-397. 
Its members were clerks and border guard officers employed on the territory of Wierzbołów Customs District. This institution started to operate very intensively and already in the first year of its operation a sum of 4,575.78 rubles was collected from donations and membership fees. In the subsequent years the income of the committee exceeded 3,500 rubles. The activity of the committee with such financial capabilities focused on one aim - supporting children from border guard and lowerrank customs officer families. Children from such families could not afford receiving proper education due to very low salaries. Moreover, even if they had a chance to get educated in local elementary schools, they comprised only a tiny proportion of the student community which was dominated by children from Roman Catholic families. This is why members of the charity committee decided to support a church-parish school functioning with the Tsar Konstantin Orthodox church in Łomża. Moreover, with proper funds, the committee could afford funding stipends for children of customs offices clerks and border guard officers to receive secondary education. Each stipend-holder would receive the support of 150 rubles a year, which fully covered the costs of education in then-current gymnasiums and pro-gymnasiums (male and female). The charity committee with the Łomża church operated until autumn 1874. Since the school year 1874/1875 the initiative in that area was taken over by CTDMF, which meant providing constant support for the education of children, which is the reason why the charity committee concluded its activity ${ }^{23}$.

At the end of 1872 a church-parish charity committee was organised by the parishioners of the church in Kibartai. This committee comprised mainly top clerks of the customs office in Wierzbołów and representatives of administrative staff of the railroad joining Wierzbołów with the rail system of the Russian Empire. This institution could afford a relatively energetic activity, enabled mainly by membership fees, proceeds from cultural events organized to support poor parishioners or donations from private persons or members of the ruling Romanov dynasty. The church charity committee in Kibartai contributed, among others, to erection of a building for a 2-grade elementary school in 1870s, which cost 8,640 rubles. However, it was worthwhile mobilising members of the charity committee to support this initiative as this guaranteed the opportunity to educate children of less affluent customs and railroad clerks from Wierzbołów and its vicinity. What is more, the involvement of customs clerks belonging to this committee in taking care over the parish cemetery and providing

23 'XBEB' 1878, 18, pp. 3-4; K. Latawiec, Rosyjska straż graniczna, p. 397. 
funding and material help for those parishioners of the Kibartai church that were most in need is quite notable ${ }^{24}$.

The parish charity committee with the Częstochowa church, operating since $20 \mathrm{March} / 1$ April 1873, was also supported by the clerks employed in the local management of Kalisz Customs District. The activity of the members of this committee concentrated on the erection of a fence around the parish church, purchase of necessary church utensils and support for the local elementary church school ${ }^{25}$.

Five years after the opening of the Orthodox parish in Sub-border Aleksandrów (3/15 October 1882) the church charity committee was established there. Its members were dominated by the clerks employed in the local customs office. The committee was chaired over by Nikolay Pyotrovich Bogoslovskiy, who was in charge of the customs office. The customs department was represented by the following clerks: Grigoriy Rodyonovich Pomeranskiy, prince Aleksey Pyotrovich Vadbolskiy, Alexander Pyotrovich Marazuyev, Aleksey Ivanovich Sidorov, and others. Moreover, border guard officers V. Lukin and A. Andreyev were also active in this institution $^{26}$. In the first years of its operation the members of the committee focused on taking care of the parish church and providing some minor material help to the less affluent members of the parish community.

In 1891 the Orthodox parish in Sosnowiec was established. Even before the Orthodox church was erected in this town, the clerks employed in the local customs office had most to say in the local Russian community. On 13/25 December 1892 Mikhal Vasiliyevich Nikonov, who was in charge of the customs office in Sosnowiec, was appointed the first chairman of the newly established church charity committee ${ }^{27}$. In 1893, with Nikonov as chairman, the committee conducted renovation of the church and churchparish school building, as well as covered the salary of this school's teacher. Moreover, the committee bought the stationery and textbooks for pupils and provided minor material help to less affluent members of the parish community $^{28}$. Nikonov's work was continued by Sergey Romanovich Bazhenov, who was also in charge of the customs office in Sosnowiec ${ }^{29}$.

When dealing with the out-of-service activities of the clerks of the customs department, what needs to be stressed is their involvement in initiatives of church construction in the area of the Kingdom of Poland.

\footnotetext{
${ }^{24}$ 'XBEB' 1878, 20, pp. 5-6.

25 Ibidem, p. 6.

26 'XBEB' 1882, 22, pp. 377-378; K. Latawiec, Rosyjska straż graniczna, p. 398.

'XBEB' 1893, 2, pp. 24-25.

'XBEB' 1894, 5, pp. 84-85.

'XBEB' 1897, 7, pp. 119-120.
} 
Once the Saint Petersburg-Warsaw Railway was joined with the Prussian railroad system, Wierzbołów customs office grew in prestige. As a result, it became one of the key customs offices on the Western border of the Russian Empire. The customs and railroad officers employed there had to use Orthodox churches that were quite distant from Wierzbołów, which is why the clerks got involved in the erection of a church in Kibartai. They played a major role in the activity of the building committee by supporting it with financial donations collected among the clerks employed in Wierzbołów customs office. The church was completed in $1871^{30}$.

The establishment of churches for customs department clerks employed in sub-border Aleksandrów and its vicinity was met with full support of Sylvester Ivanovich Lvovskiy. This chairman of Aleksandrów Customs District became the chairman of the building committee in the first days of January of 1874. He coordinated works on the architectural design and cost estimate of church construction. Moreover, he supervised construction of a church in Sub-border Aleksandrów until he was promoted to the position of chief of Saint Petersburg Customs District. S. Lvovskiy's position as chairman of the building committee was taken over by Gustav Nikolayevich Fixen, who succeeded Lvovskiy as chief of Aleksandrów Customs District ${ }^{31}$.

The level of involvement of customs officers in the religious activity external to their service can be best exemplified by the circumstances of church construction in Grajewo ${ }^{32}$. Grajewo customs office (classified as a first-class unit) started its operation on 1/13 June 1873. After a few months it became one of the key customs offices on the area of the Kingdom of Poland, which resulted in the influx of people of Russian origin and Orthodox denomination to Grajewo and its surroundings. Orthodox church believers, who were employed in Grajewo customs office, were under the jurisdiction of the parish priest of Saint Konstantin Orthodox church in Łomża. Relatively large distance from the main church was the reason why the idea of construction of a new Orthodox church in Grajewo was put forward and the main initiators of this idea

30 'Пермския Епархиальныя Ведомости' 1872, 4, р. 36.

31 RGIA, f. 21, inv. 11, ref. no. 232, fol. 1-44; K. Latawiec, A. Górak, J. Legieć, S. Bogdanow, op. cit., pp. 113-117.

${ }_{32}$ The decision to establish a customs office in Grajewo was taken due to the construction of the railway line from Brest to East Prussia. The existence of Grajewo customs office was sanctioned by the ukaz of the Tsar of 27 May/8 June 1870. The office started its operation since 1/13 June 1873. Полное Собрание Законов Российской Империи, собрание второе, vol. XLV, отделение первое, 1870, Санкт Петербург 1872, no. 48420, pp. 728-729; vol. XLVIII, отделение первое, 1873, Санкт Петербург 1876, no. 52341, p. 786. 
were the clerks of the local customs office. As early as in 1874 they filed a petition to the Minister of Finance to allow construction of a church in Grajewo. In 1875 these attempts were supported by CTDMF director Nikolay Alexandrovich Kachalov. After a few months of consultations between the Minister of Finance and Warsaw Governor-General some part of funds for the church construction were secured. In spring 1876 the building committee was established, and it was dominated by the clerks of the local customs office (among others, the chairman of the committee was the chief of Wierzbołów Customs District Nikolay Grigoryevich Dyakonov, while the vice-chairman was Konstantin Karlovich Palshau, who was in charge of the customs office). Moreover, in the work of the committee partook Vladyslav Osipovich Piltz (1834-24 June 1886), an architect-engineer of Wierzbołów Customs District, who was supervising engineering works. Great involvement of the members of the building committee resulted in erection of a shell of a church building in 1877 . Over the next year the church was under finishing. The consecration of the Equal-to-the-Apostles Mary Magdalene Orthodox Church took place on 22 October/3 November $1878^{33}$.

The construction of an Orthodox church in Granica proceeded in a similar manner. The employers of customs offices in Granica and Sosnowiec as well as border guards protecting the border of the state in this area belonged to the Orthodox parish community in Olkusz. In 1875 the clerks from both offices put forward a request for permission to erect a church in Granica. This started relevant procedures and, as a result, the design and cost estimate of the building were made by V. O. Piltz and were authorized by Warsaw Governor-General on 9/22 June 1876. Next, the building committee was established and it was supposed to coordinate the works related to this investment. As before, the committee was dominated by customs officers. The chairman was Alexander Nikanorovich Kurlov, chief of Kalisz Customs District. The committee's members were Aleksey Ivanovich Sidorov (in charge of Granica customs office), Vladimir Ivanovich Petrini (member of Granica customs office), Syemyon Syemyonovich Yakovlev (member of Granica customs office), Vladimir Pavlovich Debil (member and in charge of Granica customs office), Alexander Pyotrovich

33 The church in Grajewo was not a customs church, it was taken over by the Most Holy Governing Synod on the basis of the ukaz of 21 June/3 July 1878. The staff of this church was supported by 1,530 rubles each year. Due to the absence of a parsonage, the chief of Wierzbołów Customs District decided to give over a couple of rooms in Grajewo customs office as accommodation for the church priest and the psalmist. 'XBEB' 1878, 2, pp. 4-5; K. Latawiec, A. Górak, J. Legieć, S. Bogdanow, op. cit., pp. 93-94; K. Latawiec, Rosyjska straż graniczna, p. 379. 
Putyato (secretary of chancellery of Kalisz Customs District), Alexander Nikolayevich Miklashevskiy (secretary of Granica customs office). All of them played a major role in the erection of the church by securing funds, purchasing building materials etc. The church was consecrated on 7/19 October $1884^{34}$.

The Chełm-Warsaw Orthodox archbishop sactified the church in Mława on 28 October/9 November 1879. This crowned more than fouryear-long efforts of customs officers employed in the management of Aleksandrów Customs District and customs offices in Pepłówek and Mława. An important role in the activities of the building committee for Mława Orthodox church was played by Gustav Nikolayevich Fixen (chief of Aleksandrów Customs District), Mikhal Vasiliyevich Nikonov (in charge of Mława customs office), Fyodor Yakovlevich Uggla (member of Mława customs office), and Yuliy Augustovich von Pistohlkors (member of Mława customs office) $)^{35}$.

As a person in charge of Sosnowiec customs office, the aforementioned V. P. Debil took his own initiative to erect an Orthodox church for the local Russian community. He was lucky to mobilise remaining Russian clerks employed in Sosnowiec and its vicinity. Himself he donated his private funds to this aim. Debil's involvement resulted in building a church named after Martyr Saints Vera, Nadhezda and Lubov between August 1888 and November 1889. His outstanding achievement was also that the newly erected church was built for around 40,000 rubles collected only from private persons. Moreover, thanks to his foresight, a parsonage was built for 7,000 rubles, which was supposed to house also a church-parish school $^{36}$.

Out-of-service activities of the customs department's clerks were also visible in Orthodox church fraternities. Such institutions were operating in the mainland Russia as early as in the $17^{\text {th }}$ century. However, they experienced rapid growth two centuries later, in particular, in 1880s. They were also created in the newly developed structures of the Orthodox church in the Kingdom of Poland. The most important institutions of this

34 Sidorov and Petrini received personal thanks from the Chełm-Warsaw Orthodox archbishop for their engagement in the activities of the building committee. 'XBEB' 1887, 14 , pp. 226-228.

${ }_{35}$ The engineering works were supervised by Zygmunt Kmita, Mława poviat architectengineer, and V. Piltz, CTDMF architect. Archiwum Państwowe w Warszawie, Oddział w Mławie, Kancelaria Wincentego Loberta notariusza w Mławie, ref. no. 2, pp. 58-81, 94-101; 'XBEB' 1879, 22, pp. 371-372; 'XBEB' 1879, 23, pp. 386-387; K. Latawiec, A. Górak, J. Legieć, S. Bogdanow, op. cit., pp. 94-95; K. Latawiec, Rosyjska straż graniczna, p. 373.

36 'XBEB' 1891, 24, pp. 413-414. 
kind were the Saint Theotokos Orthodox Fraternity in Chełm and the Holy Trinity Fraternity in Warsaw ${ }^{37}$.

It was rather rare for Orthodox church fraternities to be established with churches of the customs department. The abovementioned church charity committees were a more popular form of activity among the church parishioners. However, one needs to mention here some attempts at establishing such institutions were made. In 1895 the parishioners of the Saint Nicholas Orthodox church in Słupca, represented mainly by the clerks from Grodzisk, Piotrków, Słupca and Szczypiorno customs offices and by Kalisz Border Guard Brigade officers, established the fraternity. This organisation adopted a similar action plan to a typical church charity committee. Funds were gathered from voluntary donations of the customs department employees and were mainly used to provide support to poor and needy parishioners of Słupca Orthodox church ${ }^{38}$.

Active involvement of customs department clerks in the existing religious and charitable institutions was noticeable until the end of their presence in the Kingdom of Poland. Further activity was interrupted by the outbreak of World War I. On the eve of the conflict's outbreak customs officers were evacuated to the mainland of the Empire, which put an end to functioning of such institutions as church charity committees or religious fraternities.

Since their first days in the Kingdom of Poland Russian clerks employed in the customs department played a crucial role in the establishment and functioning of local Orthodox religious communities. They did that mainly for moral reasons. Education with the respect for the values of the Orthodox church and an inherent need to help others motivated clerks to become involved in all kinds of initiatives as described above. Seeing such proposals, local administrative authorities enabled their operation by issuing legal regulations upon their functioning. The emergence of the opportunities to support one's own church or provide charity help had a mobilising effect on the representatives of the Russian clerical staff of the customs department, which had its effect on the way a number of institutions described above functioned.

37 See S. Dmitruk, Prawosławne Bractwo Przenajświętszej Bogurodzicy w Chetmie (18791914), Lublin 2012, Ph.D. dissertation manuscript, Maria Curie-Skłodowska University Main Library.

38 'XBEB' 1898, 2, p. 22. 


\section{REFERENCES}

\section{Archival Sources}

Archiwum Parafii Prawosławnej w Częstochowie:

Akta stanu cywilnego Parafii Prawosławnej w Częstochowie: ref. no. year 1872

Akta stanu cywilnego Parafii Prawosławnej w Olkuszu: księga chrztów z lat 1857-1864.

Archiwum Narodowe w Krakowie:

Akta stanu cywilnego Parafii Prawosławnej w Olkuszu: ref. no. 1.

Rossiyskiy Gosudarstvennyy Istoricheskiy Arkhiv:

f. 21 , inv. 11 , ref. no. 232

f. 908 , inv. 1 , ref. no. 329

f. 1349, inv. 5, ref. no.: 828, 1467, 2066, 2216, 2443, 2753, 3174, 3294, 3914, 5033, 5253, 5293, 5692, 6464, 7126, 7398, 7915, 8178, 8976, 9138.

Archiwum Państwowe w Częstochowie:

Akta stanu cywilnego Parafii Prawosławnej w Częstochowie: ref. no. 1

Akta stanu cywilnego Parafii Prawosławnej w Krzepicach: ref. no. 1-12.

Archiwum Państwowe w Katowicach:

Akta stanu cywilnego Parafii Prawosławnej w Olkuszu: ref. no. 1/60, 2/12, 2/35.

Archiwum Państwowe w Kielcach, Oddział w Sandomierzu:

Akta stanu cywilnego Parafii Prawosławnej p.w. św. Michała w Zawichoście: ref. no. 2.

Archiwum Państwowe w Warszawie, Oddział w Mławie:

Kancelaria Wincentego Loberta notariusza w Mławie: ref. no. 2.

\section{Printed Sources}

'Kholmsko-Varshavskiy Yeparkhial'nyy Vestnik' 1877-1879, 1881-1882, 1884, 1887, 1891, 1893-1894, 1897-1898.

'Permskiya Yeparkhial'nyya Vedomosti' 1872.

Polnoye sobraniye zakonov Rossiyskoy Imperii, sobraniye vtoroye, vol. XXV, otdeleniye vtoroye, 1850, no. 24598, Sankt Peterburg 1851.

Polnoye sobraniye zakonov Rossiyskoy Imperii, sobraniye vtoroye, vol. XLV, otdeleniye pervoye, 1870, no. 48420, Sankt Peterburg 1872.

Polnoye sobraniye zakonov Rossiyskoy Imperii, sobraniye vtoroye, vol. XLVIII, otdeleniye pervoye, 1873, no. 52341, Sankt Peterburg 1876.

Rocznik urzędowy Królestwa Polskiego na rok 1866, Warszawa [no date of publication].

Rocznik urzędowy obejmujacy spis naczelnych władz Cesarstwa oraz wszelkich władz i urzędników Królestwa Polskiego na rok 1862, Warszawa [no date of publication].

Rocznik urzędowy obejmujacy spis naczelnych władz Cesarstwa oraz wszelkich władz i urzędników Królestwa Polskiego na rok 1863, Warszawa [no date of publication].

Ustawa celna dla Królestwa Polskiego, Warszawa 1851.

\section{Studies}

Dmitruk S., Prawosławne Bractwo Przenajświętszej Bogurodzicy w Chetmie (1879-1914), Lublin 2012, Ph.D. dissertation manuscript, Maria Curie-Skłodowska University Main Library.

Latawiec K., Duchowieństwo cerkwi prawosławnych resortu celnego i straży granicznej w Królestwie Polskim w latach 1851-1914, 'Res Historica' 2014, 37.

Latawiec K., Rosyjska straż graniczna w Królestwie Polskim w latach 1851-1914, Lublin 2014.

Latawiec K., Górak A., Legieć J., Bogdanow S., Naczelnicy organów rosyjskiej administracji specjalnej w Królestwie Polskim w latach 1839-1918. Słownik biograficzny, vol. 2, Ministerstwo Finansów, Lublin 2016.

Sławiński P., Prawosławie w Sandomierzu i okolicy, Warszawa 2008. 


\section{STRESZCZENIE}

Od 1851 r. na terenie Królestwa Polskiego funkcjonowała rosyjska administracja celna. W strukturach terenowych Departamentu Opłat Celnych Ministerstwa Finansów pojawiło się wielu urzędników pochodzenia rosyjskiego i wyznania prawosławnego. Zaczęły kształtować się lokalne społeczności rosyjskie, które bardzo często skupiały się wokół urządzanych cerkwi prawosławnych. Przez cały okres obecności tej administracji, od połowy XIX w. do 1914 r. urzędnicy celni i funkcjonariusze straży granicznej z własnej inicjatywy angażowali się w różne projekty związane z funkcjonowaniem Kościoła prawosławnego i aktywnością na polu dobroczynną. Władze carskie bardzo przychylnie odnosiły się do tych oddolnych inicjatyw. Bardzo chętnie akceptowały zaangażowanie się urzędników w komitety budowlane cerkwi, w tworzenie i funkcjonowanie cerkiewnych parafialnych komitetów opiekuńczych czy bractwa religijne. Chęć pomocy macierzystej świątyni parafialnej czy biednym parafianom działało mobilizująco na przedstawicieli rosyjskiego inteligencji urzędniczej zatrudnionej w resorcie celnym. Inicjatywy te nasiliły się po 1864 r. i były zauważalne do chwili wybuchu I wojny światowej.

Słowa kluczowe: urzędnik, komora celna, Rosjanin, prawosławie, cerkiew

\section{ABOUT THE AUTHOR}

Krzysztof Latawiec - PhD, currently holds the position of assistant professor at the Department of Archives and Auxiliary Sciences of History at the Institute of History at Maria Curie-Sklodowska University in Lublin. His range of interests covers the issues regarding the presence of Russian citizens in the Kingdom of Poland and the presence of Poles within the Romanov Empire, and the functioning of education, the judiciary, and state administration in the territory of Poland in the late 19th and early 20th century. He is the author of the following book publications: W stużbie imperium... Struktura społeczno-zawodowa ludności rosyjskiej na terenie guberni lubelskiej w latach 1864-1915, Lublin 2007; Rosyjska straż graniczna w Królestwie Polskim w latach 1851-1914, Lublin 2014, and the co-author of Polacy na wschodniej Ukrainie w latach 1832-1921, Lublin 2012 and 2014 (the ukrainian version available under the title Поляки в Центральній та Східній Україні у 1832-1921 роках, Київ 2017); Słownik biograficzny gubernatorów i wicegubernatorów w Królestwie Polskim (1867-1918), Lublin 2014 and 2015; Rosyjska administracja specjalna w Królestwie Polskim w latach 1839-1918, Lublin 2015; Naczelnicy organów rosyjskiej administracji specjalnej w Królestwie Polskim w latach 1839-1918. Słownik biograficzny, vol. 1, Ministerstwo Oświecenia Publicznego, Lublin 2015; Polacy w guberni połtawskiej na przełomie XIX i XX wieku, Lublin 2016; Naczelnicy organów rosyjskiej administracji specjalnej w Królestwie Polskim w latach 1839-1918. Stownik biograficzny, vol. 2, Ministerstwo Finansów, Lublin 2016; Russian Governors in the Kingdom of Poland (1867-1918), Lublin 2016; Naczelnicy organów rosyjskiej administracji specjalnej w Królestwie Polskim w latach 1839-1918. Stownik biograficzny, vol. 3, Zarzad skarbem, finansami, przemystem $i$ handlem, Lublin 2018; Depolonizacja Ziem Zabranych (1864-1914). Koncepcje Mechanizmy decyzyjne - Realizacja, vol. 2, Prawobrzeżna Ukraina. Czasy Annienkowa i Bezaka (1864-1868), Kielce 2018. E-mail: latawiec@poczta.umcs.lublin.pl. 